\title{
Longo caminho da morte (1971) e as fronteiras entre o Cinema Novo e o Cinema Marginal
}

\author{
Gabriel Henrique de Paula Carneiro ${ }^{1}$
}

Longo caminho da morte teve sua primeira exibição pública em 1971, mas parece ter sido descoberto apenas em 2016, quando ganhou nova cópia, em digital, para exibição na mostra Cinema de Invenção ${ }^{2}$, em São Paulo. Desde então, o filme itinerou com a mostra pelo Rio de Janeiro, na Cinemateca do MAM, e teve exibições especiais no festival Olhar de Cinema, em Curitiba, e na Cinemateca Capitólio, em Porto Alegre, entre outros, além de ser exibido pela primeira vez na televisão, no Canal Brasil, tudo em 2017.

Costumeiramente tratado como uma produção tardia do efervescente cinema moderno paulista, o filme pouco repercutiu à época. Após exibições especiais na Cinemateca do MAM, em 25 de junho de 1971, e no Cine Belas Artes, em São Paulo, em 22 de setembro de 1972, e longa batalha contra a Censura, o filme estreou comercialmente em 9 de setembro de 1974, no Cine Marachá, em São Paulo. Ganhou dois textos: um rápido comentário de Rubem Biáfora $(1974,28)$ na coluna Indicações da Semana, e uma crítica de Pola Vartuck $(1974,19)$, em sua segunda e última semana em cartaz, ambos no jornal $O$ Estado de S. Paulo.

Jairo Ferreira tratou do filme pela primeira vez por ocasião do ciclo Cinema Marginalizado, na ECA/USP, em crítica para a Folha de S. Paulo (1978). Posteriormente, o crítico incluiu Longo caminho da morte em seu livro sobre cinema de invenção (Ferreira 2016), que de certa forma o alinha, historiograficamente, ao cinema de vanguarda brasileiro. No entanto, ainda que conste na filmografia referencial, o longa não é abordado no estudo de Fernão Ramos sobre o cinema marginal (Ramos 1987) ${ }^{3}$, lançado na mesma época do livro de Ferreira, ambos pioneiros na pesquisa sobre essa produção, e não foi apresentado em nenhuma das várias edições da extensiva mostra Cinema Marginal Brasileiro e suas Fronteiras, realizada pela Heco Produções (Puppo 2004), duas das principais fontes de pesquisa sobre o tema. Apesar de considerado uma das obras fundamentais sobre o Cinema Marginal, escrito pelo principal cronista do período, Cinema de invenção, busca se afastar desse rótulo e traz um escopo bastante

\footnotetext{
${ }^{1}$ Jornalista, diretor de filmes, crítico e pesquisador de cinema.

2 A mostra teve como recorte os filmes abordados no livro homônimo de Jairo Ferreira (2016), e aconteceu no CineSesc, entre 23 e 30 de novembro.

${ }^{3}$ Mais recentemente, em seu artigo sobre o Cinema Marginal, Ramos (2018b, 179180) aborda brevemente Calasso e o filme como parte do grupo próximo ao teatro Oficina.
} 
pessoal e largo, que engloba Mário Peixoto e Walter Hugo Khouri, por exemplo.

O chamado Cinema Marginal ${ }^{4}$ passou por algumas revisões críticas, o que de certa forma legitimou os filmes a ele associados, tidos inicialmente como 'malditos', em especial pelo tratamento da Censura, que baniu muitas dessas obras e cortou outras tantas. Longo caminho da morte, no entanto, passou praticamente incólume por esse revisionismo e continuou 'maldito' - 'o maldito entre os malditos' , assim como seu realizador, o cineasta, produtor, ator e roteirista Júlio Calasso Jr. Poucos escritos se detêm mais atentamente sobre ele uma exceção talvez seja o dossiê temático a seu respeito na revista digital Zingu! (2012). Esse limbo aonde Longo caminho da morte e Calasso permaneceram talvez tenha duas razões. Uma delas seria a dificuldade de acesso ao filme, cuja única cópia, em película, se deteriorou bastante desde sua realização. Por isso, sua descoberta parece efetivamente se dar apenas em 2016, quando o filme se difunde com o digital, chegando à televisão e, de maneira pirata, à internet. A segunda seria que Longo caminho da morte, ainda que tenha muito do que se convencionou chamar de Cinema Marginal, aparenta se alinhar também à estética do Cinema Novo, em especial o de sua fase mais tardia. Margeando tais movimentos, o lugar de Longo caminho da morte é indefinido.

A partir dessa premissa, este artigo pretende, justamente, investigar os pontos de aproximação e de afastamento deste filme em relação tanto ao Cinema Novo quanto ao Cinema Marginal, e tentar entender se ele realmente pode ser compreendido dentro dessas filmografias e como.

\section{Júlio Calasso (1963-1971)}

Dentro dessa proposta, parece-nos interessante entender como se deu o percurso artístico do paulistano Júlio Calasso Júnior (1941) até à realização de Longo caminho da morte. Há duas balizas no começo de sua carreira: o cinema e o teatro. Em 1964, Calasso iniciou o curso de interpretação teatral com Eugênio Kusnet ${ }^{5}$, que resultou na encenação da peça Um caso em Irkutsk, de Aleksei Nikolaevič Arbuzov, dirigida por Kusnet no Teatro Oficina em 1965. Calasso frequentava também

\footnotetext{
${ }^{4} \mathrm{O}$ termo Cinema Marginal carrega em si diversas polêmicas e seu conjunto de filmes ganhou nomes diversos, como Cinema de invenção, Udigrúdi, Cinema Marginalizado etc., justamente pela dificuldade em aceitar um rótulo colocado ao conjunto de produções à revelia dos diretores, que não compunham propriamente um movimento cinematográfico organizado. Utilizo o termo Cinema Marginal aqui, como poderia utilizar qualquer um dos outros, para tratar de uma certa produção, contracultural, que nasceu de uma cisão com o Cinema Novo, com características estéticas, narrativas e práticas similares, cujo apogeu se deu entre 1968 e 1971 (Ferreira 2016; Puppo 2004; Ramos 1987, 2018b; Stam 1995).

${ }^{5}$ Eugênio Kusnet (1898-1975), russo, imigrou para o Brasil no final dos anos 1920. Foi ator, diretor e professor de interpretação, sobre o qual escreveu dois livros. Era herdeiro do sistema de atuação da escola de Stanislavski, que buscava um realismo psicológico e a externalização de emoções autênticas ao personagem, a partir de uma investigação interna sobre suas motivações.
} 
o Cineclube do Centro Dom Vital, na época capitaneado por, entre outros, Maurice Capovilla ${ }^{6}$. No mesmo ano em que iniciou o curso com Kusnet, entusiasmado com a apresentação de Cinco vezes favela (1962), Calasso abordou Capovilla, interessado em fazer filmes. Conseguiu, dessa forma, seu primeiro trabalho num set, carregando o tripé da câmera em Subterrâneos do futebol (1965), dirigido por Capovilla (Carneiro 2012a).

Calasso, assim, seguiu paralelamente as trajetórias da atuação no teatro e dos bastidores cinematográficos. Após Subterrâneos, fez assistência de direção para Geraldo Sarno em Viramundo (1965), produzido por Thomaz Farkas ${ }^{7}$. No teatro, seguiram-se Reportagem de um tempo mau (1965), de Plínio Marcos, no Teatro de Arena, pelo Grupo Barraca - do qual era diretor, com Cláudio Mamberti, Carlos Takaoka e Walter Cunha -; Se correr o bicho pega, se ficar o bicho come (1966), texto de Oduvaldo Vianna Filho e Ferreira Gullar, com direção de Gianni Ratto, em O Galpão; e O processo (1967), de Franz Kafka, dirigido por Leo Lopes, no Arena, entre outros (Carneiro 2012a; Calasso 2011).

É importante destacar que as obras que mais marcaram Calasso enquanto espectador e o influenciaram a se aventurar ao estudo e à prática teatral e cinematográfica foram a peça Pequenos burgueses (1963), de Máximo Gorki, com direção de José Celso Martinez Corrêa, o Zé Celso, no Teatro Oficina, e o filme Deus e o Diabo na Terra do Sol (1964), de Glauber Rocha. Ambas as obras foram vistas com diferença de meses entre si, às portas do golpe militar de 1964 (Carneiro 2012a). Uma das primeiras peças do Oficina ${ }^{8}$, Pequenos burgueses, fazia um paralelo entre a Rússia pré-revolucionária e o Brasil de então, com uma encenação realista amparada pelo sistema de atuação de Stanislavski. Calasso conta, de maneira hiperbólica, que deve ter visto a peça umas 120 vezes: "Comecei a chorar de emoção. Essa poesia doida; era ali que queria continuar minha vida" (Carneiro 2012a). Sobre o filme de Glauber, Calasso aponta que foi um "impacto", "uma abertura de horizonte": "Era um negócio novo, uma forma nova, com um protagonista que tinha minha idade e se parecia comigo, na forma de se posicionar diante da vida e da arte" (Carneiro 2012a).

\footnotetext{
${ }^{6}$ Maurice Capovilla (n. 1936) foi jornalista, com passagem pela revista Brasiliense e pelo Jornal da Tarde, entre outros, e é cineasta. Dirigiu, por exemplo, Bebel, garota propaganda (1967) e O profeta da fome (1970).

7 Thomaz Farkas (1924-2011) produziu ou coproduziu 38 documentários entre 1964 e 1981. O conjunto de sua produção, conhecida como 'Caravana Farkas' e considerada uma das mais importantes do documentário brasileiro, debruçou-se sobre a realidade brasileira e as manifestações culturais populares das mais diversas regiões do país, preocupado em mostrar a condição de vida do povo.

8 O Teatro Oficina, hoje ainda em funcionamento e liderado por José Celso Martinez Corrêa, acompanhou as mudanças culturais e ideológicas brasileiras dos anos 1960 . Formado em 1958, ainda de maneira amadora, com o objetivo de se opor ao burguês Teatro Brasileiro de Comédia (TBC), ícone das artes cênicas paulistas, o Oficina teve uma fase calcada na montagem realista antes de se radicalizar na experimentação, em 1967, influenciado pela contracultura, por Bertolt Brecht e em sintonia com o Tropicalismo, tendo como marco a peça O Rei da Vela (1967), a partir de Oswald de Andrade.
} 
O efeito de Pequenos burgueses e de Deus e o Diabo na Terra do Sol em Calasso diz muito, não só sobre o momento histórico brasileiro, mas também sobre a própria formação artística do cineasta e ator. No teatro, a encenação realista do método ensinado por Kusnet se alinha ao conteúdo contestatório de esquerda. No cinema, a epopeia do homem nordestino, sertanejo, oprimido, vista em Deus e o Diabo na Terra do Sol, talvez o principal expoente do Cinema Novo, encontra a forma documental mais moderna, naquele momento, nos dois filmes que Calasso fez como equipe técnica, Subterrâneos (1965) e Viramundo (1965), cuja abordagem compreendida como cinemaverdade é, para o próprio Glauber Rocha (2004, 398), “a raiz documentarística do Cinema Novo". Ou seja, Pequenos burgueses e Deus e o Diabo não são apenas balizas teóricas; são pontos de partida para ele pensar e agir artisticamente, escolher projetos a que se vincular.

Num primeiro momento, atuar lhe rendeu mais frutos. Além das peças constantes, fez As Minas de Prata (1966-67), na TV Excelsior, onde foi chamado pela Tecla Produções para ser assistente de produção de João Silvério Trevisan no longa Anuska, Manequim e Mulher (1968). A função em Anuska lhe rendeu o convite para trabalhar na produção de $O$ Bandido da Luz Vermelha (1968). Começou como assistente e logo assumiu o posto de diretor de produção - tendo feito também uma ponta como ator. Como diretor de produção, fez ainda República da Traição (1970) e Prata Palomares (1971).

Calasso não conhecia os responsáveis por O Bandido antes de ser contratado, mas rapidamente se inseriu no grupo ligado ao Cinema Marginal e acompanhou as discussões que estavam no âmago daquela produção contracultural (Carneiro 2012a). Fazer República da Traição e Prata Palomares indica essa integração. Carlos Alberto Ebert, que dirigiu República da Traição, foi fotógrafo e câmera de $O$ Bandido, bem como de Prata. André Faria, diretor de Prata, havia sido assistente de câmera de Ebert em República da Traição. Além do mais, Prata Palomares é um filme parido pelo Oficina, com roteiro de Faria e de Zé Celso. Nesse momento, o Oficina já havia dado a guinada para a verve agressiva contracultural. Em seu caminho teatral, Calasso reencontrou esse novo Oficina como ator, integrando o elenco da segunda montagem de Galileu Galilei (1970), de Bertolt Brecht, encenado por Zé Celso.

Esse era o meio pelo qual Calasso circulava e encontrava sintonia intelectual quando realizou Longo caminho da morte. Filmado na virada de 1970 para 1971, em poucos dias, com um orçamento mínimo e muitas parcerias ${ }^{9}$, numa fazenda em Serra Negra (SP), onde

\footnotetext{
${ }^{9}$ Sobre a duração das filmagens, Calasso, em entrevista para o autor, falou em oito dias de filmagem (Carneiro 2012a); para O Estado de S. Paulo (1972, 7), falou em 16 dias. Diz ele: "[O dinheiro] vinha de três fontes. Uma era minha. Uma era da minha sogra, que tinha me dado um milhão do dinheiro da época. E uma era de minha amiga, que me deu outro milhão. O que seria uns $\mathrm{R} \$ 100$ mil hoje, mais ou menos. O cachê era uma miséria. (...) Tinha uma equipe enxuta. O Rudá de Andrade me emprestou a câmera da ECA/USP [Escola de Comunicação e Artes da Universidade
} 
tinha controle de tudo - da alimentação à hospedagem -, o longa, à época intitulado $O$ Mistério da Casa Maldita, conta com uma equipe com a qual Calasso já estava familiarizado desses outros filmes vinculados ao Cinema Marginal, bem aos moldes do que Fernão Ramos (1987, 94) descreve como o modelo dessas produções: "pequenos recursos, filmagens em poucos dias, equipe e atores 'amigos', completa liberdade para exploração 'autoral'”. Longo caminho da morte é coescrito por Claudio A. Polopoli - que tivera a mesma função em República da Traição -, fotografado por Peter Overbeck - que também fez O Bandido -, montado por Calasso e por Jovita Pereira Dias - que montou República da Traição com Ebert e fez assistência de montagem em $O$ Bandido -, além de contar com assistência de direção de Cláudio Mamberti, que ele conhecia desde o começo da carreira teatral, e da então estudante Tânia Savietto.

\section{Entre os flancos da modernidade: Cinema Novo / Cinema Marginal}

Longo caminho da morte acompanha a decadência da oligarquia através de três gerações do 'coronel' Orestes (Othon Bastos) e seu relacionamento com as mulheres que o rodeiam - a mãe Mariazinha, a esposa Irene e a amante Zina (respectivamente, Assunta Perez, Rosangela Pinheiro e Cecília Thumin). Tal recorte, no entanto, não tinha a preocupação de alguns filmes de modelo clássico narrativo que remontam a episódios da história do Brasil, como forma de ilustrar o passado - caso dos filmes históricos da Cinedistri, por exemplo, como Lampião, o rei do cangaço (1963) e Independência ou morte (1972). A escolha pelo agrário, inclusive, o afasta da produção do Cinema Marginal, que preferia os cenários urbanos, e da qual Calasso era mais próximo. Nesse sentido, o interesse pelo campo e pelo passado (ainda que o tempo do filme não possa ser exatamente precisado) como maneira de percorrer a derrocada da oligarquia do começo do século XX se aproxima muito mais da produção do Cinema Novo, que nunca perdeu de vista o processo histórico brasileiro. $\mathrm{O}$ espaço de referência da produção cinemanovista de certa forma sempre girou em torno das áreas rurais - com exceções mais sistemáticas às produções feitas logo após o golpe militar em 1964, que refletiam a crise da classe média de esquerda frente à falência do projeto político.

de São Paulo] com a condição de que levasse três alunos pra serem assistentes. A equipe era de cinco pessoas, mais três caras que vieram da ECA. Um veículo que era da prefeitura, a fazenda era de graça. (...) O filme tinha 68 planos no roteiro e tem 86 planos na tela. Era plano-sequência. Além de ser linguagem, era necessidade. Ensaiava três horas e rodava uma vez. Fazia três minutos de manhã, três minutos à tarde, estava com o dia feito. Tinha que inventar um troço pra dar conta do que tinha” (Carneiro 2012a). Além da escolha do plano-sequência por questão de linguagem e de pouco negativo disponível, a fala chama a atenção para o fato de haver uma enorme preparação para a rodagem, com longos ensaios com a câmera, mesmo que a estrutura narrativa fosse bastante anárquica. $\mathrm{O}$ improviso, ao que parece, passa ao largo e as cenas não traduzem a espontaneidade presente na maioria dos filmes ditos marginais. 
Mesmo nas obras tardias do Cinema Novo, com as quais Longo caminho da morte parece se conectar mais fortemente, como Os deuses e os mortos (1970), de Ruy Guerra, e S. Bernardo (1972), de Leon Hirszman - todos protagonizados por Othon Bastos -, o sertão é central. Muda-se, no entanto, a chave interpretativa. Se, na primeira fase do Cinema Novo, o interesse é essencialmente pelo camponês, na fase derradeira os mandatários ganham protagonismo - vide, por exemplo, Os herdeiros (1969), de Cacá Diegues ${ }^{10}$. Longo caminho da morte, no entanto, desloca o espaço da narrativa do Nordeste Guerra filma na Bahia, Hirszman no Alagoas, só para ficar nesses casos mais próximos - para o sertão paulista, tendo como cenário uma fazenda de café. A mudança não é trivial. A produção cinemanovista é realizada entre Rio de Janeiro e Bahia, olhando para as mazelas mais gritantes daquele momento, no Nordeste. O olhar de Calasso é de alguém de São Paulo, cuja história é toda perpassada pela produção do café - e pela política do café. A relevância do Estado para o país só passa a existir, em meados do século XIX, com o lucro das plantações cafeeiras. A formação desse núcleo econômico se transforma em capital político e atinge seu auge na República Velha, com o golpe de 1889 amparado pelos barões do café, cuja manutenção teve no coronelismo uma das políticas de base. O fenômeno do coronelismo não é exclusivo do Nordeste, como se quer perpetuar no imaginário popular (Fausto 2019), e Calasso sabe disso. Não é à toa que ele queira desmistificar um dos bastiões da 'locomotiva do Brasil'. Nesse sentido, seu corte é muito diferente de um Terra é sempre Terra (1951), de Tom Payne, por exemplo, um dos poucos filmes brasileiros sobre esse contexto até então. Na produção da Vera $\mathrm{Cruz}^{11}$, a decadência da oligarquia é vista com um misto de saudosismo da tradição e de esperança para com a industrialização. Não há bem uma crise, e sim uma possibilidade de renascimento: São Paulo continua como um sonho de prosperidade. Em Longo caminho da morte, feito vinte anos depois, o sonho não existe mais; São Paulo é palco de contradições sociais. Situar a decadência no interior paulista, coisa que nunca interessou ao Cinema Novo, tem, portanto, contornos assertivos em inserir o Estado no debate não só pela urbe, e de reconhecer esse espaço como ancestral, mas perpétuo, como construção daquele hoje. Ou seja, ainda que não esteja propriamente no mesmo corte do Cinema Novo, há um diálogo com essa produção e uma abertura para um contexto não trabalhado anteriormente, mas facilmente vinculável.

No horizonte do Cinema Novo sempre esteve o povo. O movimento nasce na esteira de cineastas como Nelson Pereira dos

\footnotetext{
${ }^{10}$ Segundo Ismail Xavier $(1997,132)$, há, nessa fase, "um movimento de 'revisão da história', sem dúvida deflagrado pelos cortes de 1964 e 1968, quando entrou em crise a teleologia de salvação que alimentava o Cinema Novo e redefiniu-se a forma da articulação entre mundo prático e fé religiosa”.

${ }^{11}$ A Companhia Cinematográfica Vera Cruz, cuja principal fase se deu entre 1949 e 1954, foi a mais substancial tentativa de assimilar o sistema de estúdio hollywoodiano no cinema brasileiro. Os filmes, de grande orçamento e narrativa clássica, foram realizados em escala industrial, dentro dos esforços da burguesia paulista de elevar a cultura no país.
} 
Santos com intenções realistas de retratar como é o 'outro' e de mostrar os mecanismos da opressão sobre ele - ou, conforme Fernão Ramos (2018a, 23), "no despertar para a consciência do outropopular, em sintonia com os dilemas da brasilidade e na reação ao estrangeiro como outro imperialista”. A relação com o povo passou por transformações ao longo dos anos, mas, salvas exceções, sempre esteve presente. A crise do pós-1964 centrada na classe média esquerdista trazia, justamente, a dificuldade de aproximar o eucineasta do outro-povo. A incomunicabilidade com o 'outro' promovia uma crise “ética”, segundo Ramos (2018b, 125-131): "É na dicotomia do 'eu', oscilando entre 'mim' e o outro-povo, que a culpa ganha lugar e a má consciência tira combustível para queimar em exasperação." Quando, nas produções tardias, volta-se ao campo e aos oligarcas, o popular continua central para os cineastas. Se em Os deuses e os mortos, o povo, na figura de Sete Vezes (Othon Bastos), precisa se igualar aos coronéis para ascender socialmente, em $S$. Bernardo, esse mesmo povo, agora na figura de Paulo Honório (Othon Bastos), se aproveita da incompetência administrativa do herdeiro da fazenda-título para 'engolir-lhe' a propriedade. Em ambos os filmes, os novos coronéis são eles próprios o povo sem consciência de classe. Em Os deuses e os mortos, o povo definha, apodrece e paira dentro da briga pelo poder. Em S. Bernardo, a gana de Paulo Honório esmaga a todos: os que o questionam, por se oporem a ele, e os submissos, por aceitarem a submissão. Guerra pontua a impossibilidade do povo reclamar o poder; Hirszman vê na falta de consciência de classe a razão da História não ser diferente ${ }^{12}$. No monólogo final de Paulo Honório, falando sobre o que São Bernardo poderia ter sido, Hirszman opta por mostrar os camponeses trabalhando nela. Só depois de nos mostrar os lavradores é que Paulo Honório passa a se remeter a eles. "Bichos! As criaturas que me serviram durante anos eram bichos", diz. A câmera foca nos camponeses em suas casas. Retratos mais abertos da família dão espaço para os rostos das mulheres e crianças que garantiam a produtividade da fazenda. Os planos são longos, estáticos. Ausente durante todo o filme, o povo humilde volta ao centro, numa mea-culpa de seu personagem (e do diretor). Em seu encerramento, Hirszman opõe a truculência do poderoso, que se colocou acima de sua classe, com um olhar terno sobre os trabalhadores, como se assim pudesse lhes restituir a humanidade que o protagonista roubou. Paulo Honório não a devolve; Hirszman sim, ao colocá-lo em foco.

Nesse sentido, Longo caminho da morte se distancia do Cinema Novo. Se o povo é guerreiro (Guerra) ou digno de respeito (Hirszman), para Calasso ele é simplesmente engrenagem, parte do processo. Na trajetória de Orestes, os empregados (Gésio Amadeu e Benê Silva), os únicos negros do filme, são praticamente invisíveis, não são nomeados e se confundem entre si. O longa abre e fecha com

\footnotetext{
${ }^{12}$ Paulo Honório nos conta sua história como se estivesse num confessionário. Seu fim é desiludido, triste, pontuando o que o levou àquela condição e também apontando a impossibilidade de ter sido diferente. Não há reconciliação consigo mesmo.
} 
cenas desconexas da linha narrativa central que mostram esses empregados na cidade em trabalhos de pouco prestígio social - um deles lava um carro na cena inicial, o outro ergue uma construção, ao término do filme ${ }^{13}$. No entanto, não lhes é reconhecida individualidade. Ao confundir os atores que desempenham a função de 'empregado' dentro da narrativa, logo no começo ${ }^{14}$, o filme parece nos dizer que pouco importa quem é aquele personagem e sim o que ele representa naquele cenário - o que não deixa de ser um comentário do diretor acerca das relações trabalhistas. A questão, no entanto, não é o povo em si, como no Cinema Novo, e sim que ele também se move e se transfigura como qualquer outro elemento presente no longa.

Esse mover-se e transfigurar-se está na tônica de Longo caminho da morte. Na primeira cena na fazenda, vemos, em uma panorâmica, pessoas sentadas, vestindo preto e com semblante triste. O cômodo tem uma aparência antiga e mal cuidada. À medida que a câmera gira, vemos uma coroa de flores, velas e um crucifixo. Após a panorâmica completa, corta-se para o contracampo, uma imagem de Orestes num caixão. Estamos vendo pelos olhos do morto. Ouvimos durante todo o tempo a terra sendo cavada. Muda-se a cena, o som permanece o mesmo. O caixão é carregado na estrada de terra frente à casa. A câmera, parada no mesmo ângulo, vê a procissão passar. Ao fim, aparece Orestes, sendo consolado por um dos presentes. Orestes atende seu próprio funeral. Ou seja, Calasso rompe com a prerrogativa temporal. Não estamos mais na construção narrativa do Cinema Novo, que traz um eixo linear de acontecimentos, ainda que essa linearidade seja fruto, por exemplo, de um flashback e que o presente diegético volta e meia apareça. Calasso delineia um tempo suspenso, em que diferentes presentes se sobrepõem. As três gerações de Orestes que o filme acompanha, na verdade, são uma só, eterna, permanente. Cada geração é como uma extensão da anterior. As pessoas transitam por aqueles espaços em diferentes eras, se encontram e se repelem, mas representam a imutabilidade da oligarquia - ainda que o mundo esteja explodindo do lado de fora. Diegeticamente, não sabemos qual é o passado remoto, o passado recente e o presente. O experimentalismo com que Calasso pensa o tempo tem muito que ver com a maneira como o Cinema Marginal entende a construção narrativa. Segundo Robert Stam (1995, 315, tradução minha), no Marginal, "a linha narrativa convencional costuma ser subvertida" e a montagem é "antiacadêmica (...), variando entre longos planos únicos estáticos (...) e uma edição delirante, rápida e frenética”. Há uma ideia de radicalizar a forma, de fazer implodir os preceitos e as expectativas, não apenas em relação ao cinema clássico, mas também em relação ao modernismo cinemanovista.

\footnotetext{
${ }^{13}$ É possível aventar a partir disso que, diante da decadência do campo, aqueles trabalhadores rurais subalternos migraram, de maneira geral, para as cidades em busca de sustento.

${ }^{14}$ Orestes faz um pedido ao empregado interpretado por Gésio Amadeu. No plano seguinte, a continuidade da ação é dada por Benê Silva, e ambos os atores se alternam até ao final da sequência.
} 
Em Longo caminho da morte, essa implosão não se dá apenas por uma narrativa fragmentada. Dá-se também por um processo contínuo de repetições e de refações, de cenas interrompidas e posteriormente resgatadas, que se extrema dentro do próprio filme. Calasso pontua: "Estava contaminado por aquilo que me interessava, a linguagem. $\mathrm{O}$ 'como' me interessava mais do que o 'quê'. $\mathrm{O}$ cinemão talvez estivesse mais interessado no 'quê' do que no 'como" (Carneiro 2012a). ${ }^{15}$ A radicalização é tamanha que expõe o próprio processo cênico, rompendo com a expectativa da história. A transfiguração de Gésio Amadeu em Benê Silva, no começo do filme, causa estranhamento. O primeiro plano da sequência é aberto, o seguinte fechado. Só quando o processo se repete é que entendemos a chave desse procedimento. Em meados do filme, Orestes dorme ao lado de Mariazinha. Emulando um ponto de vista subjetivo, a câmera foca em Orestes, que acorda, e se aproxima. A câmera se afasta e vemos Irene, nua, de joelhos, no chão, ao lado da cama. Num plano médio, Mariazinha se vira, diz "você demorou hoje querida" e se levanta. O movimento se repete, mas toda a ação é vista num só plano que se abre após enquadrar Irene. A câmera se demora no ato de Orestes chicotear Irene num acesso verborrágico entre raiva e loucura e, por fim, se afasta, na direção de onde entrou em quadro, e reenquadra Mariazinha de costas. Novo corte. O ângulo muda para uma plongée, Mariazinha continua o movimento do plano anterior, mas numa nova configuração. Ela caminha em direção a Orestes, dormindo com Irene, sempre nua, ao seu lado. A cena prossegue como das outras vezes, com Mariazinha e Irene invertendo os papéis. Vemos a mesma cena três vezes, cada uma com novos elementos. A forma como Calasso elenca as cenas não pode ser compreendida dentro de uma progressão temporal. A reinterpretação da cena parece servir o propósito de construir Orestes como um só - um ser independente da sua geração e da mulher ao seu lado - bem como o propósito de explorar sua barbárie. Sua truculência é enfatizada pela sequência seguinte, que traz um demorado e explícito abate de bois, comparado, numa montagem que lembra as atrações soviéticas, ao espancamento da mulher.

\footnotetext{
${ }^{15}$ Vale ressaltar que, nesse contexto, a pecha de 'cinemão', pejorativa, também abarca a produção cinemanovista do final dos anos 1960 e começo dos anos 1970, que passou a fazer filmes caros, a cores, pensando em alcance de público como forma de repercutir a mensagem (Stam 1995, 311-312; Ramos 2018b, 117-121). O próprio Glauber Rocha $(2004,186)$, em entrevista de 1969, defendia que "o cinema novo seja o cinema brasileiro: comunicando-se com seu público, tendo seu próprio mercado, exportando".
} 

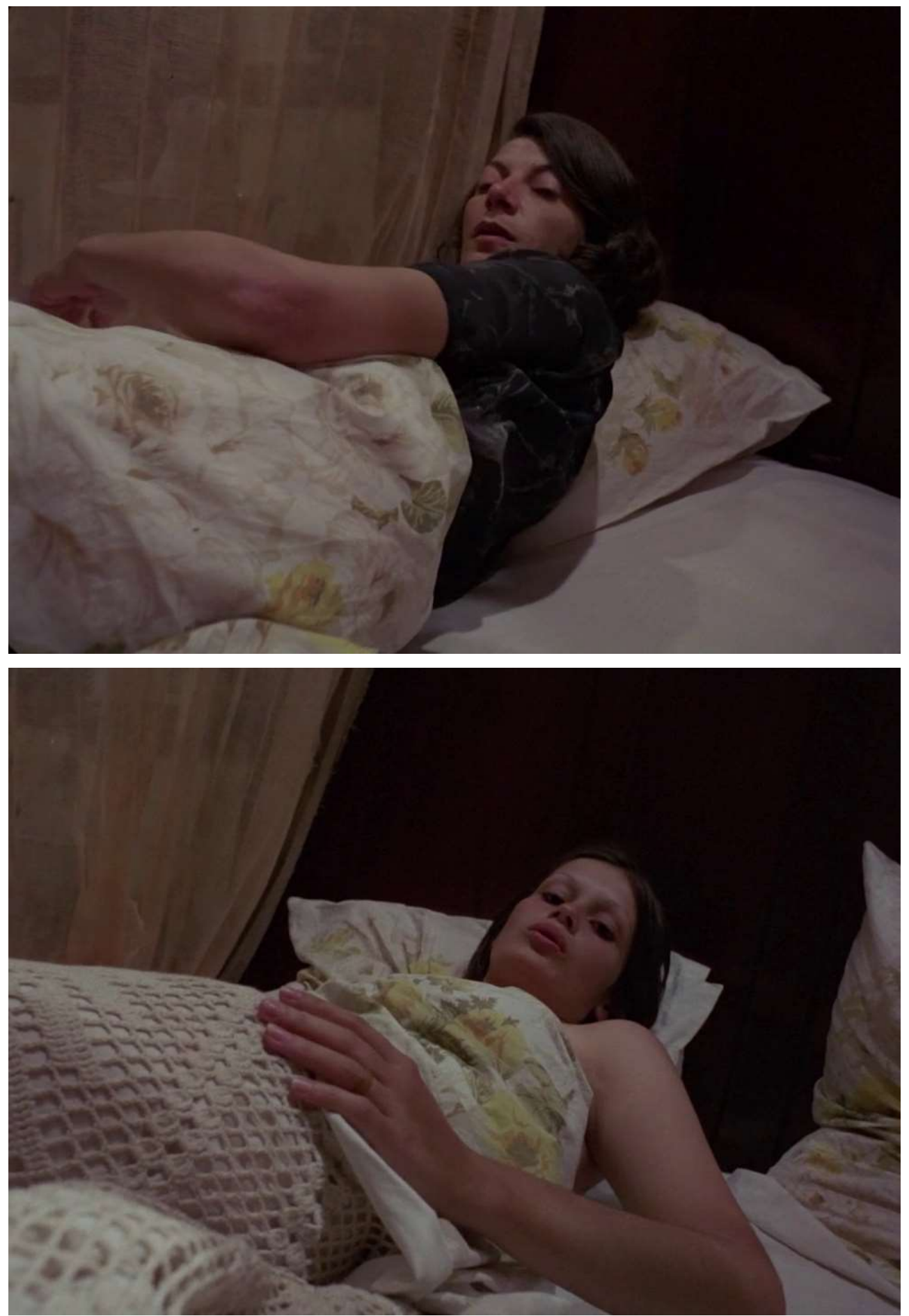

Imagens 1 e 2: Refações e inversões: diferentes personagens fazem a mesma ação | (c) Júlio Calasso Jr.

O entrecho dá a noção da gravidade na encenação de Longo caminho da morte. No horizonte do filme está sempre o horror. Não propriamente o horror enquanto gênero narrativo cinematográfico, ainda que orbite esteticamente por ele, mas a opressão do fim e da morte e o efeito fantasmático que ele provoca. A iminente decadência da fazenda, do cultivo de café durante a Crise de 1929 e a Depressão, metamorfoseia-se no fim daquela própria existência. A morte não está 
simplesmente à espreita, ela cerca todos os cômodos. "É preciso pensar seriamente no problema da morte", anuncia Orestes. "Quando eu era moço, acreditava que fosse imortal. Sério, acreditava mesmo. Tinha certeza que não morreria nunca. Quando meu velho pai rezava pelos mortos, eu sabia que ninguém nunca faria o mesmo por mim." Orestes conta, então, sobre o falecimento do pai, num acidente de barco, que o fez vislumbrar a própria morte. O monólogo, declamado de maneira lenta, é encenado em uma espécie de galpão de tijolos, abandonado. Calasso filma um plano aberto, estático, sem iluminação interna. A forte luz de fora respinga pelas janelas, dando uma noção mínima do espaço por onde Orestes circula. Calasso, no entanto, nos nega a imagem e acentua o peso do discurso. Orestes nos fala da morte como se já estivesse dentro do esquife, ao som de uma música solene. Há um impacto maior nesse enterro do que nos planos do personagem deitado morto, justamente, porque ele está vivo, ativo. Em especial porque a morte dele está intimamente ligada à morte da fazenda. Há um corte desse caixão para um plano aberto da estação da Luz, com pessoas desembarcando do trem e subindo a escadaria. No meio dos transeuntes, vemos Orestes, reduzido à insignificância das concentrações populosas das urbes.

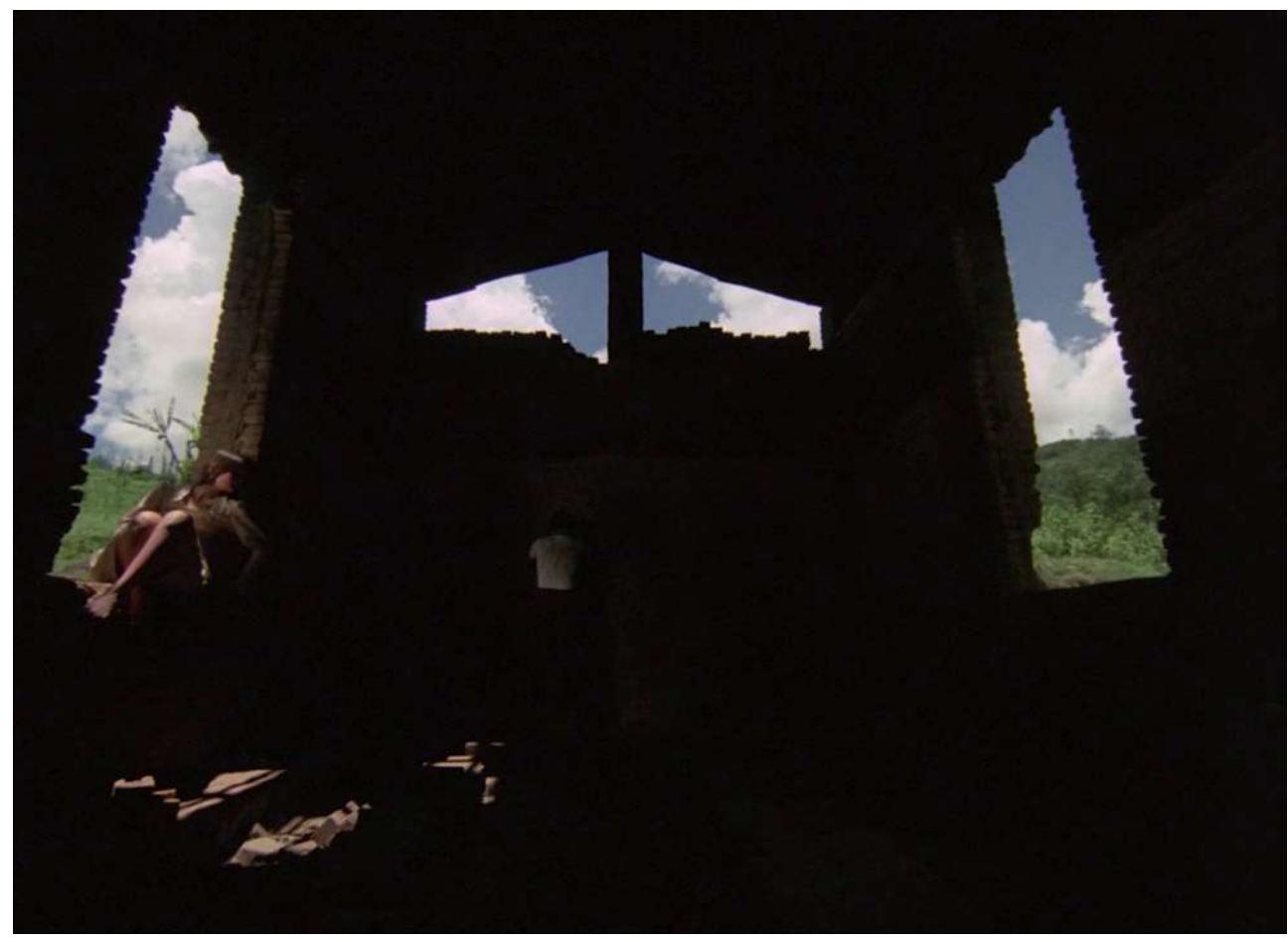

Imagem 3: O esquife de Orestes | (c) Júlio Calasso Jr.

Uma das inspirações para Calasso - o "livro de linguagem mais sofisticada de que me lembro" (Carneiro 2012a) - foi o romance Crônica da Casa Assassinada (1959), de Lúcio Cardoso ${ }^{16}$, sobre a

${ }^{16}$ Lúcio Cardoso (1912-1968) foi um escritor brasileiro, cuja obra é marcada por uma abordagem intimista e introspectiva sobre a vida e a condição humana, com 
decadência moral de uma família, adaptado para o cinema pelo cinemanovista Paulo Cezar Saraceni como A casa assassinada (1971). A figura da casa, tanto no romance, quanto em Longo caminho da morte, emana uma aura sobrenatural. Nas narrativas tradicionais góticas, as histórias de casas mal assombradas são bastante comuns. Segundo Noël Carroll (2004, 98, tradução minha), elas "recontam a possessão da vida dos novos habitantes da casa com o propósito de reencenar um mal passado (casas mal assombradas são geralmente assombradas pelo pecado de antigos habitantes)". Tal definição não deixa de se enquadrar em Longo caminho da morte; porém, as fronteiras, como visto, entre o passado e o presente são praticamente inexistentes e, portanto, tanto os habitantes antigos quanto os atuais ganham contornos fantasmagóricos, como se os mortos continuassem a habitar os corpos. A dimensão da morte, aqui, vale dizer, é diferente da que vemos em Os deuses e os mortos, que também traz os mortos à vida. Neste, o defunto locomove-se como um cadáver, um mortovivo, putrefato, assumindo o caráter de assombração para os de fato vivos $^{17}$; naquele, a morte parece da ordem espiritual, em que os fantasmas e os vivos são os mesmos, sem infligir um mal evidente. Não à toa, Calasso gosta de filmar, em longos planos-sequência, as minudências da casa, com a câmera passeando pelos cômodos, atentando-se à decoração, aos objetos, às fissuras das paredes, e também às personagens, em especial as mulheres, caminhando sozinhas pela casa, a esmo, seja ao som de música clássica de tom sombrio (Debussy, Wagner), seja com as vozes over dessas personagens em fluxo, preenchendo o espaço.

A fantasmagoria também se manifesta na interação entre personagens. Em determinada cena, Irene pergunta a Zina se ela conheceu Mariazinha, a mãe de Orestes, e ela responde que não, que Mariazinha havia morrido um tempo antes de ela chegar. Pouco depois, nessa mesma sequência, a da festa, Irene, Zina e Mariazinha estão lado a lado. Estar morto, portanto, não é um impedimento para habitarem e interagirem no mesmo tempo-espaço (que é abstrato e, por conseguinte, único).

A polifonia de vozes e a declamação diarreica, sem tempo para pausas, comuns ao longa, também são traços que podem se associar ao estado horrífico. Em Longo caminho da morte, são constantes as cenas em que, especialmente Orestes, vomita o verbo. O conteúdo das falas nem sempre importa, e sim o ato performático histriônico. O longa se encontra a meio caminho entre o tom de epopeia brechtiana, em que a fala declamada remete ao cênico, ao maior que a vida, presente em todas as fases do Cinema Novo, de Deus e o Diabo na Terra do Sol a Os

proeminente preocupação com a linguagem. Crônica da Casa Assassinada é considerado seu principal romance. Foi também dramaturgo e roteirista.

17 Sobre Os deuses e os mortos, Xavier (1997, 133) aponta: "São encarnações e imagens 'suspensas', presentes desde a sequência de abertura, que deixam claro o quanto estamos penetrando um universo marcado pela morte, habitado por fantasmas, espécie de mundo de danação onde até a retórica persuasiva de um motorista de caminhão adquire uma tonalidade de advertência profética a anunciar a desgraça." 
deuses e os mortos, e a radicalização Marginal, cujas "figuras arquetípicas (...) são a animalidade, a escatologia, o berro demorado, a gargalhada, o disforme, o pantagruélico" (Ramos 2018b, 190). Em Longo caminho da morte, no entanto, ainda que Othon Bastos incorpore a dimensão performática para a interpretação, essa performance nunca se propõe a explicitar a própria encenação. Calasso alterna entre a contenção quase apática e desdramatizada das mulheres e a expansão de Bastos, que, à medida que o filme progride, torna-se mais delirante, dramático e desvairado.

Na sequência final, após um plano centrado no rosto de Orestes olhando para a câmera, à beira da cama com a amante, urrando, em off, um berro que pode ser tanto de prazer quanto de desalento, a fazenda está pegando fogo. O plano bem aberto mostra o fogo consumindo o local e Orestes gesticulando largamente ao lado de Irene. Em plano único, a câmera se aproxima e se afasta de Orestes e do fogo pelo zoom. Orestes anda, grita, se repete, vomitando falas, se joga no chão, comportando-se de maneira quase animalesca. Diz:

Acabou! O fogo, acabou! Só o fogo pode salvar, Irene. Acabou, acabou tudo, é o fogo. O homem vai ser tragado, tragado pelo fogo. $\mathrm{O}$ homem vai ser devorado pelo fogo, devorado, Irene, devorado, devorado, Irene, eu disse, eu sempre disse, Irene. Eu fiz de tudo, Irene, eu fiz de tudo, Irene, de tudo. O mundo foi invadido pelas bestas. Elas invadiram, elas misturaram tudo, elas conspurcaram tudo, elas sujaram tudo. Agora ele compreendeu, mas agora é tarde, Irene, é tarde, é tarde. As bestas populam o universo, elas asfixiam o ar, o ar, o ar, o ar, o ar. Ah, ah, ah. Eu estou sem ar, eu estou sem ar. Olha aí, Irene, olha aí, está vendo aquela nuvem, aquela nuvem, aquela nuvem é a poeira da cidade, é a poeira da cidade, é a maldita nuvem, é a sujeira, é a sujeira, Irene, é a sujeira. Eles copulam! Eles sopram dia e noite, dia e noite, Irene, eles sopram dia e noite sem parar, eles sopram, todos sopram, agora é tarde, agora é tarde, Irene, tudo acabou, tudo acabou, Irene, é tarde, é tarde, acabou, Irene. Acabooou! Acabou, Irene, acabou. O vendaval foi soprado pelos idiotas há mais de cinquenta anos, Irene, há mais de cinquenta anos, há mais de cinquenta anos eles misturaram tudo, eles misturaram tudo, eles misturaram tudo, Irene, eles misturaram, eles misturaram, é uma massa só, é uma massa só, Irene, ela vai explodir tudo, Irene, vai explodir tudo. A Terra vai se abrir, Irene, vai se abrir e nós seremos tragados, Irene, tragados pelo fogo, pelo fogo, pelo fogo, Irene, pelo fogo, Irene, pelo fogo. É o inferno, Irene, é o inferno, é o inferno. Olha, Irene, olha no céu, no céu, Irene, no céu, no céu, no céu. Eu tenho um câncer na garganta, as bestas, elas sopram, ahhhh.

Orestes constantemente se reporta a Irene, mas em momento algum olha para ela. É como se falasse para o céu, para o abismo. As falas são repetitivas, fragmentadas, sem clareza. Importa menos aqui o teor, o peso do discurso e da palavra. Refletem, no entanto, o desespero, num procedimento que, de certa forma, lembra a encenação proposta por Antonin Artaud (2006, 146), em voga no contexto, em que, “(...) ao lado desse sentido lógico, as palavras serão tomadas num sentido encantatório, verdadeiramente mágico - por 
sua forma, suas emanações sensíveis e já não apenas por seu sentido". Longo caminho da morte não se molda às inclinações teóricas do Teatro da Crueldade, mas é evidente que nas palavras, nos discursos, muito presentes no filme, a gravidade está muito mais em torno da emissão, do desenho sonoro, do gesto (o remoer, o ressoar, o moverse e transfigurar-se), do que propriamente do conteúdo.

Pelo tom trágico, o filme aproxima-se, assim, da desilusão e do estilhaçamento político do Cinema Novo, reincidente desde Terra em Transe (1967), que baliza filmes como Os deuses e os mortos e $S$. Bernardo. No entanto, no Cinema Novo, a desesperança está na inconformidade com o outro; a destruição é externa - mesmo em filmes que bebem diretamente nele, mas não pertencem ao mesmo grupo, como Desesperato (1968) e A vida provisória (1968). Em Os deuses e os mortos, por exemplo, Ismail Xavier $(1997,156)$ aponta um embate entre a "lei do sangue" e a "lei do ouro", com a "vitória do mundo desencantado da ordem mercantil". Em Longo caminho da morte, o inimigo, se é possível assinalar um, é o próprio Orestes. Ele que coloca fogo na fazenda. Se o ato tem muito que ver com a própria derrocada dos cafeicultores, que tiveram de queimar seus estoques durante a crise, para impedir a falência, dentro dos esforços getulistas para salvaguardar a classe e a economia brasileira naquele momento (Fausto 2019), está ligado também ao caráter autodestrutivo que contamina a geração contracultural de 1968 do Cinema Marginal. Em O Bandido da Luz Vermelha, filme-chave do movimento, Sganzerla já clamava que "o terceiro mundo vai explodir" - presente na reinterpretação de Orestes de que "vai explodir tudo" e de que "a Terra vai se abrir" - , e que, "quando a gente não pode fazer nada, a gente avacalha, avacalha e se esculhamba". Orestes renegar sua trajetória, mandar tudo às favas e colocar fogo na fazenda e na casa é sua forma de "avacalhar" e de se "esculhambar" - esculhambar a si mesmo - , e de se autodestruir. A falta de horizonte está em si mesmo, por isso cabe-se infligir a morte e não esperar por ela.

Ainda que não toque na questão, o que talvez esteja por trás do horror e da agonia do filme é o horror e a agonia da ditadura militar, em que "junto com este desmoronamento [das ilusões reformistas] e a consequente incapacidade ou impossibilidade de uma ação política nos termos anteriormente estabelecidos surge um clima de tensão onde o terror e a paranoia parecem dar o tom predominante" (Ramos 1987, 29). Calasso filma no final de 1970, começo de 1971. Muita coisa aconteceu desde o primeiro Cinema Marginal, em 1968, 1969, que se apropria do caldo tropicalista. O cineasta pondera que o que talvez tenha afetado o filme para ter esse efeito tenha sido o contexto em que país se encontrava posteriormente ao Ato Institucional n. ${ }^{\circ} 5^{18}$, promulgado em dezembro de 1968. Enquanto fazia República da Traição, sofreu um acidente automobilístico que o deixou de cama por

18 O AI-5, como ficou conhecido, permitiu ao presidente fechar o Congresso Nacional e as Assembleias Legislativas, a intervenção em Estados e municípios, a censura prévia em obras artísticas e da imprensa, a suspensão do habeas corpus por crimes de motivação política, entre outros. 
um ano e meio. Nesse período, ficou incomunicável e conta que foi muito procurado pelos militares. Ele relembra:

A minha primeira mulher, a Tânia, saiu de casa às 5h. Às $6 \mathrm{~h}$, os caras chegaram. Destruíram meu apartamento, roubaram as joias dela (...), comeram a comida da geladeira, cagaram em cima da minha cama e queimaram os meus livros. Antes de saírem, metralharam meu apartamento. Dei uma sorte, porque vários dos meus parceiros morreram. Outra parte sequestrou o embaixador. Fiquei andando numa maca, sendo escondido. Pra alugar um apartamento, naquela época, você tinha que levar uma ficha de aprovação em todas as delegacias, inclusive a de ordem política e social, o DOPS. Os zeladores eram parceiros da polícia e todo mês tinham que relatar as atividades no prédio pros caras. Pra arrumar um apartamento, teve que ser no nome do meu irmão, meu pai gastou uma puta grana com o zelador. [Em Longo caminho da morte], não [quis expurgar a questão da ditadura]. Fiz porque fiz. Claro, esses dados todos estavam me contaminando. (Carneiro 2012a)

Talvez por isso, Longo caminho da morte seja tão diferente do que se associa à estética Marginal, em especial à produção paulista ligada à Boca do $\operatorname{Lixo}^{19}$ - mas não só - , como a antropofagia oswaldiana ${ }^{20}$ e a absorção do camp e do intertexto cinéfilo; o deboche, o desbunde e a curtição, que aproximam o filme do humor e da irreverência; e o questionamento estético do padrão de 'bom gosto' através da aposta no 'mau gosto' ${ }^{21}$. Longo caminho da morte não tem nada disso, numa época em que até produções ligadas ao Cinema Novo já ensaiavam uma aproximação a tais características ${ }^{22}$.

\footnotetext{
${ }^{19}$ Geograficamente, a Boca do Lixo está situada no centro de São Paulo. Nos anos 1950, recebeu esse nome por ser pauta das crônicas policiais da cidade. A proximidade com as estações ferroviárias da Luz e Júlio Prestes atraiu o cinema, pois era mais fácil e mais barato para a distribuidora e/ou produtora transportar as cópias dos filmes. A partir dos anos 1960, a Boca se tornou o principal polo produtor cinematográfico do país, congregando produtores, técnicos, diretores, atores e intelectuais nas cercanias da Rua do Triumpho. Berço do chamado Cinema Marginal e responsável por uma grande variedade de filmes de gênero a partir dos anos 1970, quase sempre com apelo erótico, a Boca do Lixo frutificou em questão de público e bilheteria, mas naufragou quanto à recepção crítica. A Boca continuou produzindo filmes populares, de baixo orçamento e sem verbas estatais até ao final dos anos 1980, quando já estava dominada pelo cinema de sexo explícito.

${ }^{20}$ Como aponta o crítico Inácio Araújo $(2004,28)$, “Oswald [de Andrade], sim, era a chave: o iconoclasta, o safado, o antropófago. (...) E como não era possível sair de uma vez [do país], que voltássemos como antropófagos, recosturando as coisas, digerindo influências, restabelecendo nexos."

${ }^{21}$ Stam $(1995,316)$ aponta como características definidoras da produção Marginal a relação intertextual com outros filmes, o metacinema e a agressividade em relação ao espectador. Ramos $(1987,43,115)$ aponta o avacalho, a curtição e a atração pelo abjeto e pela agressão, bem como a estilização e a fragmentação narrativa. Apenas a agressividade - no sentido de negar constantemente ao espectador o prazer narrativo - e a fragmentação narrativa aparecem no filme de Calasso.

${ }^{22} \mathrm{Em}$ Os deuses e os mortos, um filme calcado em longos planos-sequência em movimento, próximos dos atores, por exemplo, há alguns planos bem abertos, estáticos, que compõem quase retratos. Há uma preocupação clara na construção da mise-en-scène desses planos, em que vários elementos preenchem o quadro, dando profundidade de campo. Neles, é comum, ao menos, um personagem central
} 
Se há um momento, no entanto, em que Longo caminho da morte abraça a estética Marginal completamente, acenando, inclusive, para o deboche, é na aparição de Asmodeus (Ari Moreira) em um penhasco para um lago. Asmodeus é um demônio da mitologia judaica, com asas e três cabeças, mas no filme é representado por um homem branco, trajando apenas uma sunga, uma capa, um chapéu, com um tridente, um colar (guia) de bolas vermelhas e pretas e uma figa, símbolos ligados ao Exu, das religiões de matrizes africanas. Asmodeus se identifica como o anjo da luxúria e da libertinagem. Ao seu lado, vemos também a Pomba Gira ${ }^{23}$. A própria imagem do demônio de sunga já denota um senso de ridículo. No entanto, é o fato desse caráter figurativo explícito só aparecer nessa sequência, em meios aos devaneios de Orestes, que aponta para o estranhamento e para o nonsense. Asmodeus e Pomba Gira aparecem para Irene, tentando cooptá-la. Irene sai do luto (um traje preto) e aceita o prazer (um vestido branco), num batismo de sangue, um sangue que sai da terra ancestral e é esfregado em seu rosto. Por si só, o pacto com o demônio já denota uma afronta à Igreja - instituição ligada à moral, aos bons costumes e aos valores burgueses tradicionais - e à personagem de Mariazinha, que clama por Deus. A associação com o transe das religiões de matrizes africanas - que, além da simbologia do Exu e da Pomba Gira, aparece na música de tambores que entoa ao fundo - é uma segunda provocação, considerando que tais religiões são vistas como impuras para certos setores judaico-cristãos. Além do mais, Irene incorpora o sexo como prazer e, portanto, transgressão. O chicote, objeto que Asmodeus designa como seu representante, tornase mais um expediente do prazer, e, nisso, mais uma provocação. O chicote havia aparecido anteriormente no filme como símbolo da opressão sádica, como instrumento pelo qual Mariazinha força Deus sobre seus empregados e também pelo qual Orestes a subjuga, conforme cena anteriormente descrita. Desconstrói-se a moral difundida do Deus cristão como pura repressão e celebra-se a transgressão pela chave do prazer. Para selar o pacto, Asmodeus, Pomba Gira e Irene se beijam, se acariciam, fazem sexo, num elogio ao prazer comum ao desbunde Marginal. É uma sequência, contudo,

distante que discursa como se estivesse num palanque eleitoral. Em uma das cenas, um barão está sentado numa poltrona, com uma mulher sentada aos seus pés. Ele fala sobre a exportação do café e sobre o caráter mercantilista da terra, enquanto come um grande pedaço de melancia. A cada fala, uma nova mordida. Há uma fina ironia na cena, que aponta para o caráter ridículo do personagem que se esbalda como um glutão enquanto vocifera discursos fabricados. A distância do plano em relação ao ator, no entanto, já dá a medida da contenção da cena, que, embora tateie o grotesco, o faz sempre com muito bom gosto. Na produção Marginal, poderia se supor que, muito provavelmente, a câmera estaria próxima ao ator, encenando em tom muito mais acima, com o suco da melancia escorrendo pela sua boca em direção ao seu colo.

${ }^{23}$ Tanto o Exu quanto a Pomba Gira são figuras ligadas às religiões de matrizes africanas existentes no Brasil, como o candomblé e a umbanda. No candomblé, Exu é uma das principais divindades ou orixás; na umbanda, é um tipo de espírito. Já a Pomba Gira é uma entidade que simboliza uma mulher livre da dominação patriarcal. 
bastante deslocada esteticamente do resto do filme, reforçando o aspecto fragmentado e anárquico da obra.

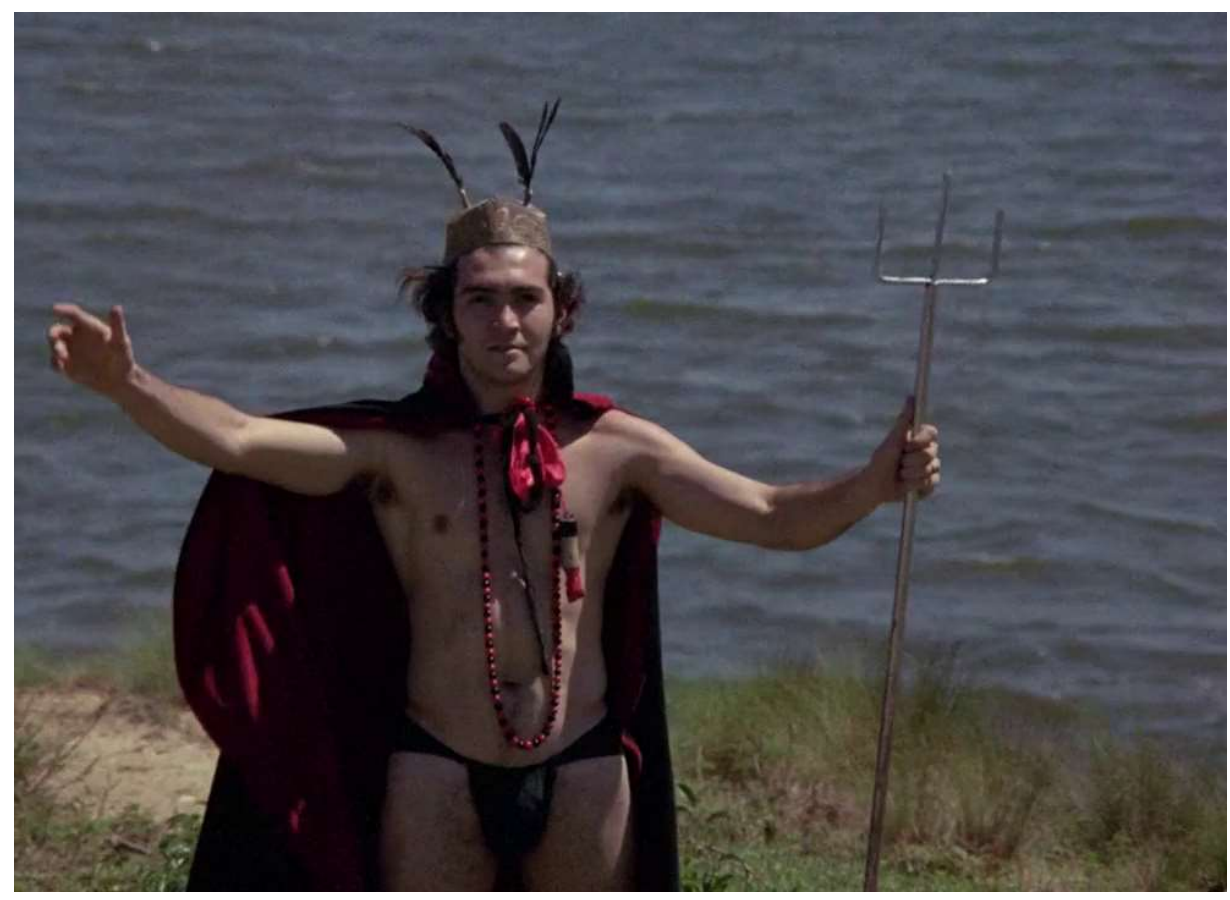

Imagem 4: Asmodeus e simbologia do prazer | (c) Júlio Calasso Jr.

A Calasso, no entanto, não interessa o rótulo de Marginal, pois, para ele, representa um estigma do qual não conseguiu se desvencilhar no cinema. Marginal "significava que não filmávamos" (Carneiro 2012a). O fato é que o longa-metragem seguinte como diretor só veio em 2013, com o documentário Nas Quebradas do Mundaréu - A viagem de Plínio Marcos. O realizador atribuiu esse afastamento do cinema e a aquisição desse rótulo a fatores externos:

$\mathrm{Na}$ realidade, muito rapidamente uma geração se estabeleceu no poder, que era a geração do Cinema Novo. (...) Tomaram conta da Embrafilme. (...) Essa é a origem. Todos eram ligados, de alguma forma, ao partidão, e tinham aquele vício de ensinar às massas e aos pobres a revolução, liderada por eles. Tem uma série de filmes didáticos, algumas grandes porcarias, e coisas muito boas também, inventivas. (...) Porque viramos marginal? Porque a grana era pouca e eles não queriam dividi-la com a gente. Grana! Nós chegamos cheio de merda de cachorro no salão deles. (...) É um lance político e de gerações, sob o patrocínio da pouca grana, além de outras circunstâncias que não estão no âmbito da arte, da estética e da ética. Marginal era isso. Se perguntar pra qualquer cara da minha época se gostava de ser chamado de marginal, ele vai te mandar à merda. É pejorativo. (Carneiro 2012a)

Ou seja, o que incomoda o cineasta é o caráter negativo que a palavra traz consigo, em especial na acepção ativa da marginalização, de "ser marginal”, como se fosse uma opção e não uma condição 
imposta - Calasso já declarou, por exemplo, preferir a expressão 'cinema marginalizado' ou a abordagem de Jairo Ferreira, 'cinema de invenção’.

\section{Considerações finais}

Parece-nos importante discutir as proximidades e os distanciamentos de Longo caminho da morte em relação ao Cinema Novo e ao Cinema Marginal, não para aprisioná-lo a um rótulo, mas, considerando que é ainda uma obra pouco estudada, para entender em que medida o filme e seu diretor se relacionam com o contexto cinematográfico e histórico em que foi realizado. Júlio Calasso foi bastante influenciado pelo teatro e pelo cinema político que despontava nos anos 1960, prégolpe militar, e isso contaminou sua obra. No entanto, o cineasta caminhou em outra direção e integrou a produção da vanguarda contracultural paulista - trajetória similar a boa parte de seus pares.

Para Calasso, o ato de fazer Longo caminho da morte é sua declaração de ruptura com as influências pregressas, das quais havia se distanciado, em especial nos momentos agônicos pós-1968: "Cinema Novo já estava me enchendo o saco. Sempre eram aqueles filmes rurais, com aqueles camponeses. Participei de muitos movimentos, sei da brutal desigualdade social. Mas, do ponto de vista cinematográfico, o outro lado era bem interessante" (Carneiro 2012a). Como vimos, trabalhar com a oligarquia, no entanto, respondia muito mais a ânsias cinemanovistas do que contraculturais - aqui, registrando os barões do café paulistas num corte inédito com o movimento. Calasso sentia "a necessidade de dizer outras coisas" (Carneiro 2012a). Para ele a questão era outra:

Estávamos empolgados com a linguagem, não com a história, os personagens. Era basicamente os delírios de um poderoso de uma história que não existe mais. O Orestes é o fim de uma história que não existe mais, a decadência, a derrocada de quem está em cima. Os camponeses inclusive passam ao largo, você só escuta o som. Depois esse cara que você não viu aparece operário em São Paulo. (Carneiro 2012a)

A fala de Calasso demonstra dois pontos de cisão com o Cinema Novo: o interesse maior pela linguagem em detrimento do conteúdo - opondo-se, especialmente, como vimos, às produções de maior acabamento técnico - e o desinteresse pelo povo. Para o cineasta, o povo é mais um som. Uma das principais reivindicações do grupo ligado ao Cinema Marginal era que o Cinema Novo se acomodou e se aburguesou, e que, na falência do projeto político-estético, deveria se radicalizar na forma, na linguagem, na revolução estética. Essa nova geração rompeu com a anterior como forma de dar continuidade ao projeto cinematográfico que, lhe parecia, havia sido abandonado, quando, na realidade, deveria ser extrapolado. Daí a estrutura fragmentária, calcada em tempos narrativos que se alternam, se mesclam e se fundem, em refações de cenas, em inversões de 
personagens. Ou, conforme aponta Robert Stam (1995, 327, tradução minha) na conclusão do que chama de "underground", a opção por "uma série de recusas - da narrativa linear, do conclusivo, da 'competência' técnica, da continuidade convencional".

Em Longo caminho da morte, é possível vislumbrar toda a argumentação do cineasta. Em suas falas, distancia-se da abordagem teleológica e condescendente de algumas fases do Cinema Novo, mas se aproxima da representação arquetípica. O desejo de renovação da linguagem, que fez parte do discurso cinemanovista, por sua vez, é o cerne da ruptura marginal na busca da radicalização - e esse é o ponto mais frequente nas falas de Calasso, que, para tal, evoca Oswald de Andrade e Lúcio Cardoso (Carneiro 2012a). No entanto, em nenhum momento, o cineasta defende bandeiras típicas do Cinema Marginal. Sua agremiação, além de geracional, parece ser mais forte no quesito (e na falta) de estrutura de produção, em que a própria técnica gira em torno do orçamento mínimo. Não à toa, Calasso não vê seu filme próximo ao dos pares da Boca do Lixo, inclusive os marginais:

O meu filme e os outros que queria fazer não tinha nada a ver com aquela estética. Eram outros riscos que estava disposto a correr. Claro, tudo aquilo contaminou. Não que tivesse tido qualquer problema com a Boca, mas não era meu único interesse. Fazia também teatro, estudava filosofia, tudo nessa época. Depois virei produtor musical. (Carneiro 2012a)

Em Longo caminho da morte, com rara exceção, não vemos a absorção do camp e do metacinema, o desbunde e a curtição, ou o humor e a irreverência. No entanto, há a evolução da desilusão cinemanovista no horror e na agonia marginal. Nesse sentido, é possível dizer que Longo caminho da morte, feito na tensão entre os dois principais movimentos do cinema brasileiro da época, pende muito mais para a contracultura marginal do que para a verve cinemanovista. Certamente, o filme é um estranho no ninho dentro dessa filmografia e, por mais que se afaste de características balizantes a essa produção, incorpora o clima de desesperança autodestrutiva que permeou tais obras, além da preocupação com uma linguagem mais solta e livre que vemos no cinema de vanguarda. Nisso, o filme de Calasso teima em se integrar completamente em qualquer recorte, mas deixa antever todo o panteão do cinema moderno brasileiro da virada para os anos 1970.

\section{BIBLIOGRAFIA}

Araújo, Inácio. 2004. "No meio da tempestade." In Cinema Marginal Brasileiro e Suas Fronteiras, organizado por Eugenio Puppo, 2728. São Paulo: Heco Produções.

Artaud, Antonin. 2006. O Teatro e seu Duplo. São Paulo: Martins Fontes. 
Biáfora, Rubem, e Carlos M. Motta. 1974. "Florinda, direção de Lumet e duas estréias nacionais.” O Estado de S. Paulo, 8 de setembro, 1974, p. 28.

Calasso Jr., Júlio. 2011. Currículo. 2011. Enviado ao autor por e-mail.

Carneiro, Gabriel. 2012a. "Entrevista com Júlio Calasso." Revista Zingu!, maio de 2012, n. 54 . https://revistazingu.net/2012/05/28/entrevista-juliocalasso/.

----. 2012b. “O longo caminho da morte.” Revista Zingu!, maio de 2012, n. 54. https://revistazingu.net/2012/05/28/o-longocaminho-da-morte/.

Carroll, Noël. 2004. The Philosophy of Horror or the paradoxes of the heart. Nova Iorque \& Londres: Routledge.

Estado de S. Paulo, O. 1972. "Diretor faz um filme sem tempo.” 22 de setembro, 1972, p. 7.

Fausto, Boris. 2019. História do Brasil. São Paulo: Edusp.

Ferreira, Jairo. 2016. Cinema de Invenção. São Paulo: Azougue.

----. 1978. “O longo caminho do Kâncer.” Folha de S. Paulo, 14 de julho, 1978, p. 39.

Labaki, Aimar. 2002. José Celso Martinez Corrêa. São Paulo: PubliFolha, coleção Folha Explica.

Miranda, Luiz Fernando. 1990. Dicionário de cineastas brasileiros. São Paulo: Art/Secretaria de Estado de São Paulo, p. 71.

Puppo, Eugenio (Org.). 2004. Cinema Marginal Brasileiro e Suas Fronteiras. São Paulo: Heco Produções.

Ramos, Fernão. 1987. Cinema Marginal (1968/1973): A Representação em seu Limite. São Paulo: Brasiliense.

----. 2018a. “A ascensão do novo jovem cinema.” In Nova História do Cinema Brasileiro, volume 2, organizado por Fernão Pessoa Ramos e Sheila Schvarzman, 16-115. São Paulo: Edições Sesc.

----. 2018b. "Cinema Novo / Cinema Marginal, entre curtição e exasperação.” In Nova História do Cinema Brasileiro, volume 2, organizado por Fernão Pessoa Ramos e Sheila Schvarzman, 116-201. São Paulo: Edições Sesc.

Ramos, Fernão Pessoa, e Sheila Schvarzman (Orgs.). 2018. Nova História do Cinema Brasileiro. 2 volumes. São Paulo: Edições Sesc.

Revista Zingu!. 2012. "Dossiê Júlio Calasso.” Maio de 2012, n. 54. https://revistazingu.net/capa-edicao-54/.

Rocha, Glauber. 2004. Revolução do Cinema Novo. São Paulo: Cosac Naify. 
Stam, Robert. 1995. "On the Margins: Brazilian Avant-Garde Cinema." In Brazilian Cinema, organizado por Randal Johnson e Robert Stam, 306-327. Nova Iorque: Columbia University Press.

Vartuck, Pola. 1974. "Fita de vanguarda revela cineasta de talento expressivo." O Estado de S. Paulo, 19 de setembro, 1974, p. 19.

Viany, Alex. 1999. O processo do Cinema Novo. Rio de Janeiro: Aeroplano.

Xavier, Ismail. 1997. "Os deuses e os mortos: maldição dos deuses ou maldição da história?" Ilha do Desterro 32(1997): 131-162. https://periodicos.ufsc.br/index.php/desterro/article/view/ $\underline{8436}$

----. 2013. Alegorias do subdesenvolvimento. São Paulo: Cosac Naify.

\section{FILMOGRAFIA}

A Casa Assassinada. Dir. Paulo Cezar Saraceni. Planiscope Planificações e Produções Cinematográficas Ltda., Brasil, 1971.

A Vida Provisória. Dir. Maurício Gomes Leite. Tekla, Saga, L. C. Barreto, J. P. de Carvalho, Brasil, 1968.

Anuska, Manequim e Mulher. Dir. Francisco Ramalho Jr. Tecla Produções Cinematográfica, Brasil, 1968.

Bebel, Garota Propaganda. Dir. Maurice Capovilla. Difilm, CPS e Saturna, Brasil, 1967.

Cinco Vezes Favela. Dir. Marcos Farias, Carlos Diegues, Miguel Borges, Joaquim Pedro de Andrade, Leon Hirszman. CPC-UNE, Saga Filmes Ltda., Brasil, 1962.

Desesperato. Dir. Sérgio Bernardes Filho. SW Bernardes Produções Cinematográfica, Brasil, 1968.

Deus e o Diabo na Terra do Sol. Dir. Glauber Rocha. Copacabana Filmes, Brasil, 1964.

Independência ou Morte. Dir. Carlos Coimbra. Cinedistri, Brasil,1972.

Lampião, o Rei do Cangaço. Dir. Carlos Coimbra. Cinedistri, Brasil, 1963.

Longo Caminho da Morte. Dir. Júlio Calasso Jr. PS Produções Cinematográficas, Taetro Sociedade Civil Ltda., Brasil, 1971.

Nas Quebradas do Mundaréu - A Viagem de Plínio Marcos. Dir. Júlio Calasso Jr. Propícia Produções, Brasil, 2013.

O Bandido da Luz Vermelha. Dir. Rogério Sganzerla. Distribuidora de Filmes Urânio, Brasil, 1968.

O Profeta da Fome. Dir. Maurice Capovilla. Fotograma Produtora e Distribuidora de Filmes, Brasil, 1970.

Os Deuses e os Mortos. Dir. Ruy Guerra. Companhia Cinematográfica de Filmes Brasileiros, Daga Filmes, Brasil, 1970. 
Os Herdeiros. Dir. Carlos Diegues. J. B. Produções Cinematográficas, Produções Cinematográficas L. C. Barreto Ltda., Brasil, 1969.

Prata Palomares. Dir. André Faria. André Faria Produções Cinematográficas, Vega I Filmes, Brasil, 1971.

República da Traição. Dir. Carlos Alberto Ebert. Ebert Polopoli, Brasil, 1970.

S. Bernardo. Dir. Leon Hirszman. Saga Filmes, Brasil, 1972.

Subterrâneos do Futebol. Dir. Maurice Capovilla. Thomaz Farkas, Brasil, 1965.

Terra é Sempre Terra. Dir. Tom Payne. Companhia Cinematográfica Vera Cruz, Brasil, 1951.

Terra em Transe. Dir. Glauber Rocha. Mapa Produções Cinematográfica Ltda., Brasil, 1967.

Viramundo. Dir. Geraldo Sarno. Thomaz Farkas, Brasil, 1965. 